\title{
Pemanfaatan GIS (Geographic Information System) untuk Memonitor Kesehatan Tanaman Kelapa Sawit
}

\author{
Application of GIS (Geographic Information System) in Monitoring \\ the Health of Palm Oil Plant
}

\author{
Andrew Stefano \\ Program Studi D3 Teknologi Geomatika, Politeknik Pertanian Negeri Samarinda \\ Kampus Gunung Panjang Jl. Samratulangi Samarinda 75131, Indonesia \\ Correspondence Author: andrew.itb2001@gmail.com
}

\begin{abstract}
ABSTRAK
Penelitian ini mengkaji dan menganalisis hubungan sensor visible dan inframerah drone dengan tanaman kelapa sawit kedepannya akan mudah melakukan memonitor tingkat kesehatan tanaman yaitu dari segi waktu dan efesiensi biaya. Lebih ke depan lagi sebagai arah tujuan jangka panjang adalah mengarah pada precision agriculture dengan memasukan unsur teknologi informasi dan mekanisasi pada bidang perkebunan. Metode yang digunakan adalah melakukan pemotretan/foto kepada blok-blok kelapa sawit menggunakan drone, dengan sensor visible dan inframerah. Hasil foto tersebut kemudian digunakan untuk analisis luas kanopi pada tanaman sawit. Luas kanopi ini bisa digunakan untuk menghitung jumlah tegakan kelapa sawit. Luas kanopi dipetakan berdasarkan bentuk kanopi dari sensor visible foto drone. Pada luasan kanopi yang dihasilkan, dianalisis lagi menggunakan foto inframerah sehingga didapat hubungan prosentase ketinggian pantulan inframerah dengan kanopinya. Prosentase ketinggian pantulan inframerah mengindikasikan banyaknya zat hijau daun atau klorofil pada tanaman tersebut dan diasumsikan semakin sehat tanaman tersebut.
\end{abstract}

Kata kunci : Citra Digital, Drone, Kelapa Sawit, GIS

\section{ABSTRACT}

This study examines and analyzes the relationship between visible sensors and infrared drones with palm oil in the future. It will be easy to monitor the level of plant health in terms of time and cost efficiency. Further forward as the long-term goal is to lead precision agriculture by incorporating elements of information technology and mechanization in the plantation sector. The method used is to take photographs / blocks of oil palm blocks using drones, with visible and infrared sensors. The results of these photographs are then used for the analysis of canopy area in oil palm plants. This canopy area can be used to calculate the number of oil palm stands. The area of the canopy is mapped based on the shape of the canopy from a visible photo drone sensor. In the resulting canopy area, analyzed again using infrared photographs to obtain a correlation between the percentage of the height of the infrared reflection with the canopy. The percentage height of the infrared reflection indicates the amount of green leaf green or chlorophyll in the plant and it is assumed that the plant is healthier.

Keywords: Digital Image, Drone, Palm, GIS.

\section{PENDAHULUAN}

Berdasar data dari Kementerian Pertanian Republik Indonesia bahwa total luas perkebunan kelapa sawit di Indonesia saat ini berkisar 10 juta hektar dan jumlah ini diperkirakan akan meningkat menjadi 13 juta hektar pada tahun 2020. Dengan luasan tersebut Indonesia menjadi penghasil kelapa sawit terbesar di dunia diikuti oleh Malaysia, Thailand, Colombia dan Nigeria. Sehingga untuk melakukan monitoring perkebunan kelapa sawit yang sangat luas tersebut dibutuhkan suatu inovasi teknologi yang lebih murah dan efisien (Mirzaeinia, Hassanalian, Lee, \& Mirzaeinia, 2019).
Perkembangan teknologi informasi dan komputer yang sangat cepat mempengaruhi cara pandang orang terhadap teknologi perkebunan secara keseluruhan. Beberapa hal yang dulunya dilakukan secara manual dan memakan waktu lama didorong untuk lebih cepat dan dilakukan secara otomatis atau digital. Sebagai contoh adalah cara akuisisi data spasial di perkebunan kelapa sawit, yang pada saat ini mulai menggunakan pesawat tanpa awak (Drone) (Driscoll, 2018).

Teknologi pemetaan dengan drone menjadi pilihan alternatif disamping teknologi pemetaan lainnya seperti pemotretan udara 
baik skala besar dan kecil berawak serta pemetaan berbasis satelit (Dugdale, Malcolm, \& Hannah, 2019). Teknologi ini sangat menjanjikan untuk diaplikasikan dikembangkan dan sesuai karakteristik topografis dan geografis Indonesia terutama untuk areal yang luas seperti perkebunan kelapa sawit (Duffy, Pratt, Anderson, Land, \& Shutler, 2018).

Pemanfaatan foto hasil pemetaan menggunakan drone biasanya digunakan untuk menghitung jumlah pokok tanaman kelapa sawit saja, sementara perkembangan ilmu di pengolahan citra dari penginderaan jauh sudah memanfaatkan banyak sensor multispektral seperti inframerah, thermal dan bahkan hiperspektral. Sehingga pada penelitian ini diharapkan dapat mengarahkan pada pemanfaatan sensor multispektral untuk memonitor dan mempelajari hubungan antara sensor- sensor tersebut dengan kesehatan tanaman kelapa sawit yang terekam oleh foto drone (Mirzaeinia et al., 2019).

Drone merupakan pesawat tanpa awak yang diterbangkan menggunakan kendali via remote, smartphone ataupun komputer (Poljak \& Sterbenc, 2019). Drone dilengkapi kamera beresolusi tinggi yang memungkinkan pengguna dapat memantau suatu lokasi tertentu dari ketinggian secara real time (Saria \& Al-sa, 2019). Dengan menggunakan Drone, data dapat diperoleh dengan biaya relatif rendah, dalam waktu relatif cepat, dan aman dalam berbagai kondisi cuaca (Sciancalepore et al., 2019).

Drone merupakan sistem tanpa awak (Unmanned System), yaitu sistem berbasis elektro-mekanik yang dapat melakukan misimisi terprogram, dengan karakteristik: (i) tanpa awak pesawat, (ii) beroperasi pada mode mandiri baik secara penuh atau sebagian, (iii) Sistem ini dirancang untuk dapat dipergunakan secara berulang (Siva, 2016).

Ada beberapa macam jenis drone, yakni fixed wing dan multi rotor. Drone Fixed Wing memberikan keuntungan dalam hal jarak tempuh dan lama terbang dibanding multi rotor. Namun Fixed Wing membutuhkan lokasi terbuka yang luas untuk take-off maupun landing (Tu, Phinn, Johansen, Robson, \& Wu, 2020). UAV Fixed Wing cocok diaplikasikan untuk survei pemetaan skala luas seperti foto udara maupun survei lainnya (Watkins et al., 2019).

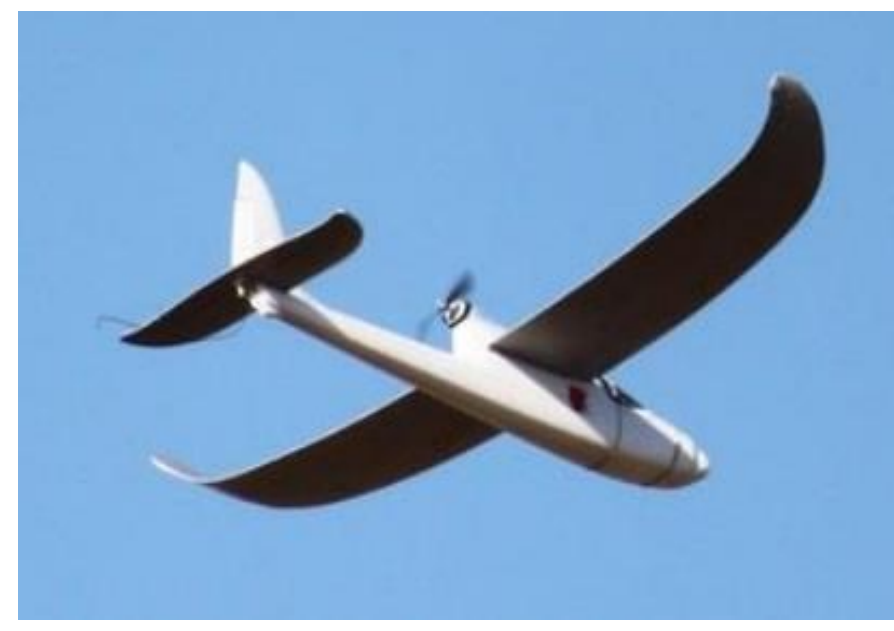

Gambar 1. Fixed Wing

UAV multi rotor cocok untuk pemetaan yang tidak mempunyai area terbuka luas untuk take-off dan landing (Driscoll, 2018). Survei dengan multi rotor memberikan keuntungan terkait dengan tingkat kedetilan objek yang dapat diperoleh (Duffy et al., 2018). Multi rotor menggunakan beberapa motor sebagai penggeraknya, sehingga membutuhkan sumber tenaga lebih. 


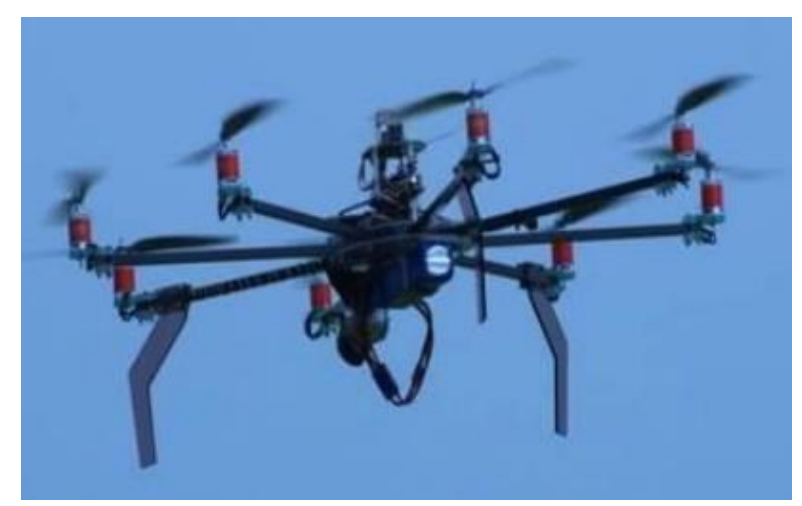

Gambar 2. Multi Rotor

Drone banyak digunakan untuk memonitor sumber daya alam (Dugdale et al., 2019). Drone mudah tersedia, dan dapat menjangkau areal yang luas, dengan perlengkapan sensor relatif kecil, GPS, dan perangkat keras yang terkait lainnya (Mirzaeinia et al., 2019). Sejauh ini drone telah digunakan untuk mendapatkan citra penginderaan jauh seperti pemantauan kebakaran dan bencana alam, pengamatan satwa liar, dan pengukuran vegetasi dalam kebun anggur, tanaman, hutan, dan "rangeland" (Poljak \& Sterbenc, 2019).

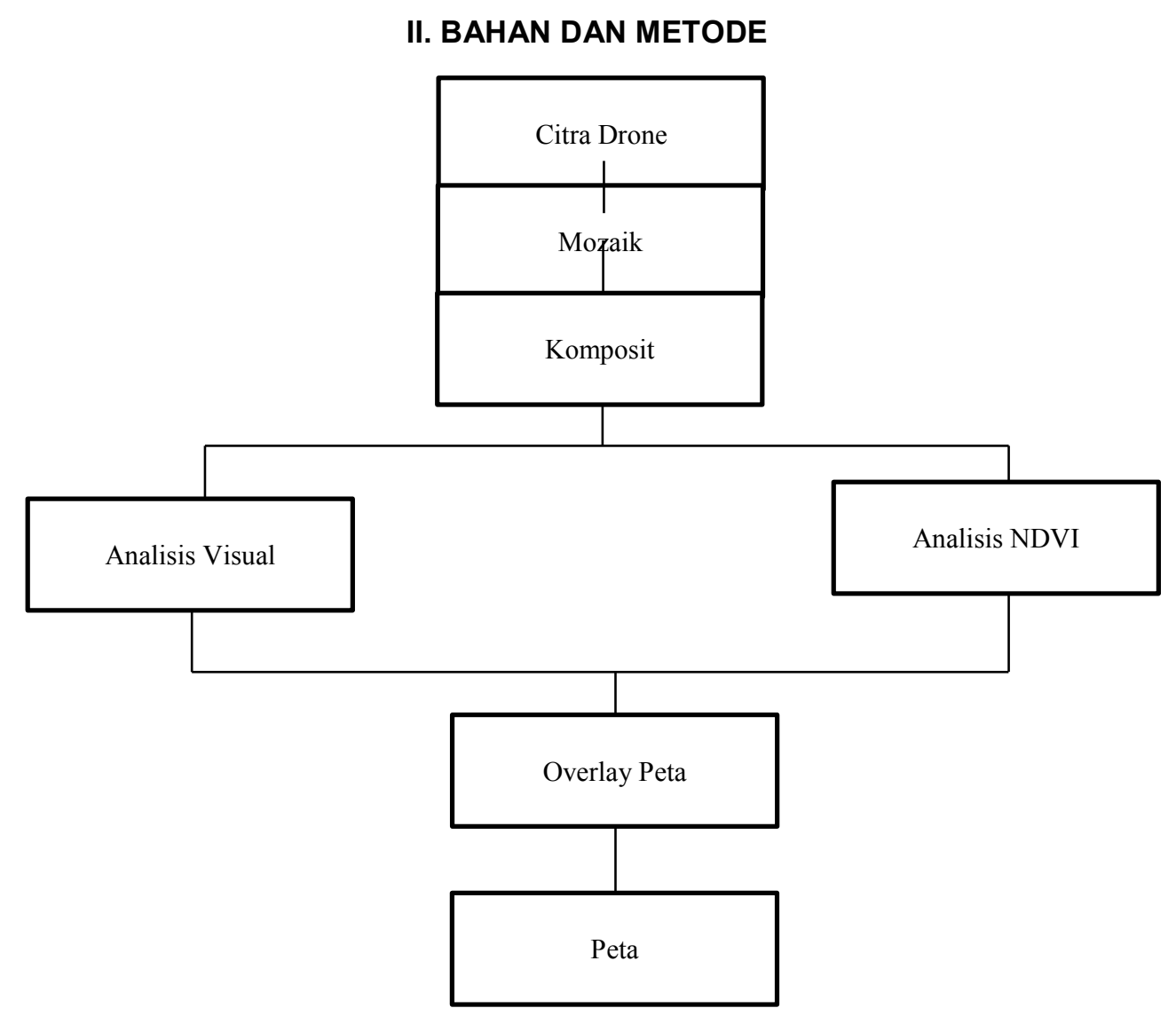

Gambar 3. Skema Penelitian 
Mozaik citra adalah menggabungkan beberapa hasil foto dari drone sehingga menghasilkan satu foto daerah secara keseluruhan. Prinsipnya adalah setiap foto mempunyai koordinat, dan bertampalan dengan foto lain di sebelahnya (Saria \& Al-sa, 2019). Penggabungan ini akan mempermudah dan mempercepat analisis dengan pandangan kebun secara keseluruhan (Sciancalepore et al., 2019). Komposit adalah pemilihan 3 saluran/band sehingga menghasilkan informasi yang lebih detil dengan memanfaatkan keunggulan tiaptiap saluran (Siva, 2016).

Citra drone standar bekerja pada band visible yang menghasilkan gambar seperti apa yang terlihat oleh mata (Tu et al., 2020). Penambahan saluran pada drone yaitu inframerah yang peka terhadap zat hijau daun akan sangat bermanfaat (Watkins et al., 2019).

Dalam penelitian penginderaan jauh dan analisis citra respon spektral pada masing- masing saluran berbeda-beda dan digambarkan dalam respon kurva pantulan berikut (Driscoll, 2018). Penggabungan ini akan mempermudah dan mempercepat analisis dengan pandangan kebun secara keseluruhan (Duffy et al., 2018).

Komposit adalah pemilihan 3 saluran/band sehingga menghasilkan informasi yang lebih detil dengan memanfaatkan keunggulan tiap- tiap saluran (Dugdale et al., 2019). Citra drone standar bekerja pada band visible yang menghasilkan gambar seperti apa yang terlihat oleh mata (Mirzaeinia et al., 2019). Penambahan saluran pada drone yaitu inframerah yang peka terhadap zat hijau daun akan sangat bermanfaat (Poljak \& Sterbenc, 2019).

Dalam penelitian penginderaan jauh dan analisis citra respon spektral pada masing-masing saluran berbeda-beda dan digambarkan dalam respon kurva pantulan berikut (Saria \& Al-sa, 2019):

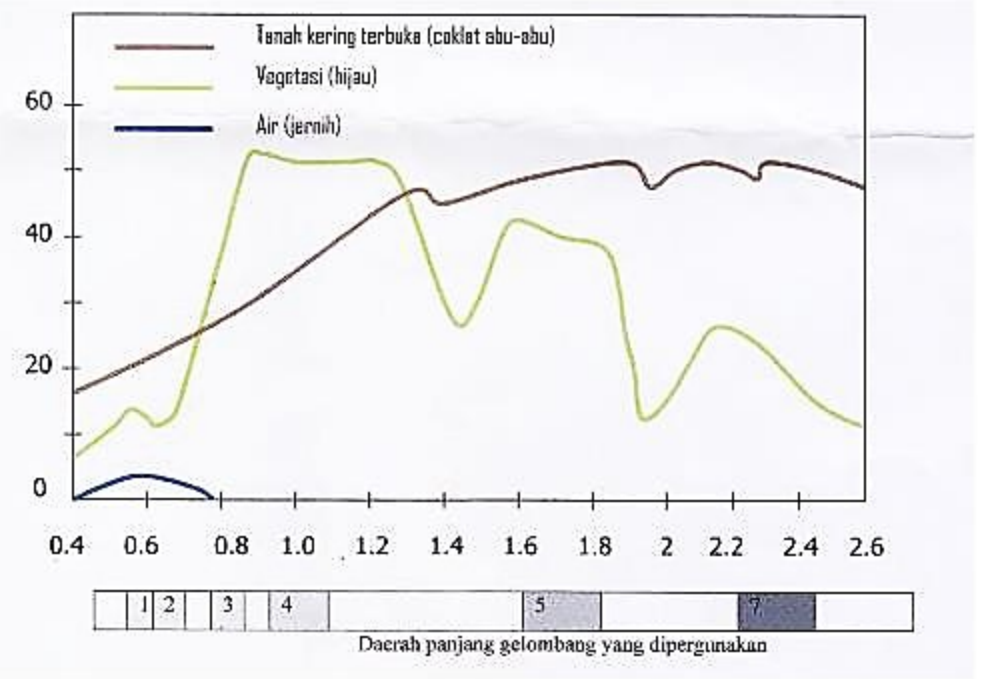

Gambar 4. Pantulan Spektral

Karakteristik kurva pantulan pada band inframerah bervariasi terdapat tiga puncak dengan persentase respon pantulan yang berbeda (Sciancalepore et al., 2019). Pada band inframerah dekat kurva pantulan berada pada pantulan yang paling tinggi $40 \%$, garis kurva turun dan naik lagi membentuk puncak kedua dengan persentase $30 \%$ dan puncak ketiga dengan persentase $20 \%$ pada band inframerah tengah (Siva, 2016).

Dilihat masing-masing band yaitu band biru $(0,4-0,5 \mu \mathrm{m})$, band hijau $(0,5-0,6 \mu \mathrm{m})$, band merah $(0,6-0,7)$, band inframerah dekat (0,7-1,3 $\mu \mathrm{m})$, dan band inframerah tengah (1,3-2,6 $\mu \mathrm{m})$ (Tu et al., 2020). 


\section{HASIL DAN PEMBAHASAN}

\section{Peta Lokasi Penelitian}

Penelitian dilaksanakan di kebun kelapa sawit PT Ketapang Agro Lestari (First Resources Group) yang berada di wilayah Kecamatan Siluq Ngurai Kabupaten Kutai Barat Kalimantan Timur. Kegiatan analisis spasial dan pemetaan seluruhnya dilakukan di ruang GIS Kantor Kebun PT Ketapang Agro Lestari (First Resources Group).

Alat dan bahan untuk penelitian ini terdiri atas GPS Garmin 64S, Laptop Core i7, DJI Phantom 4 Pro, Meteran, Bendera Pancang, Tongkat, parang, shapefile blok kebun PT Ketapang Agro Lestari, shapefile jalan, parit, dan terasan. Selain itu, adapun perangkat yang digunakan adalah ArcMap 10.3, Global Mapper, MapSource, DJI Phantom Go, DroneDeploy, dan Agisoft PhotoScan Professional.

Penelitian ini dilaksanakan melalui beberapa tahapan-tahapan, yaitu: tahap persiapan, dimana pada tahap ini mempersiapkan kebutuhan yang diperlukan pada saat dilakukannya suatu pekerjaan, salahsatunya dalam kegiatan verifikasi sisip dan pokok antara lain peta sub-blok dan flight plan untuk rencana jalur terbang drone.

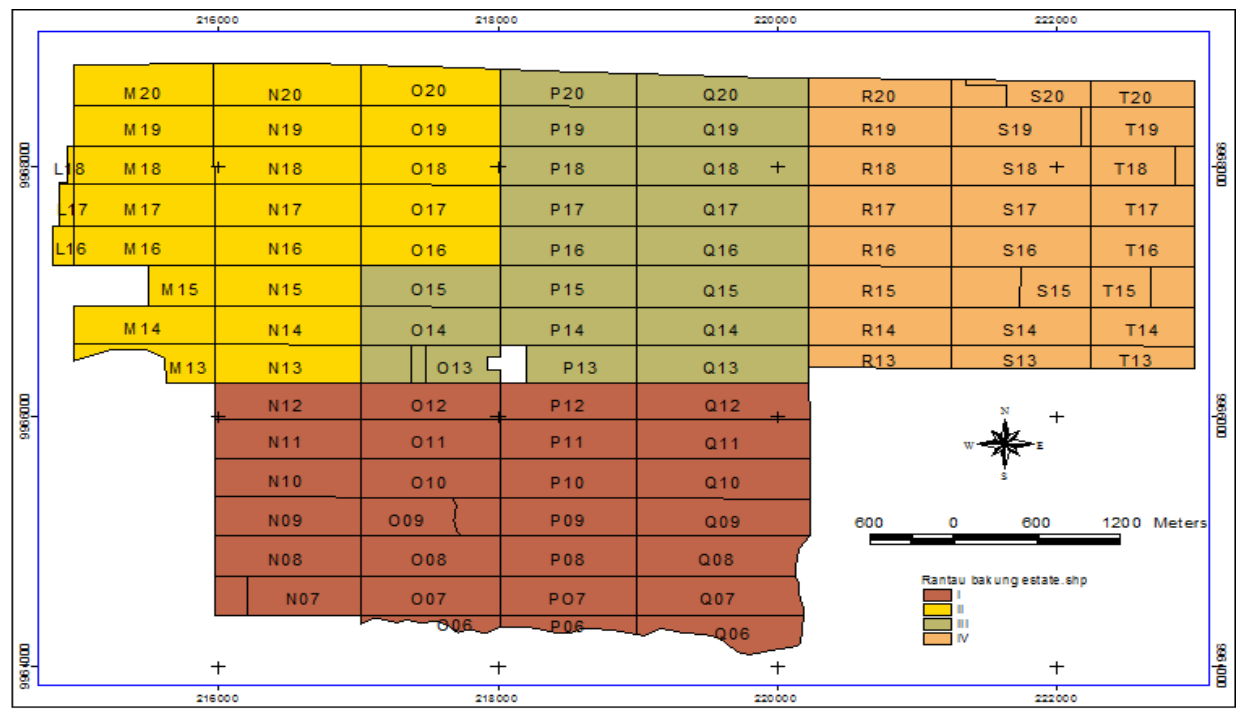

Gambar 5. Lokasi Kebun Penelitian

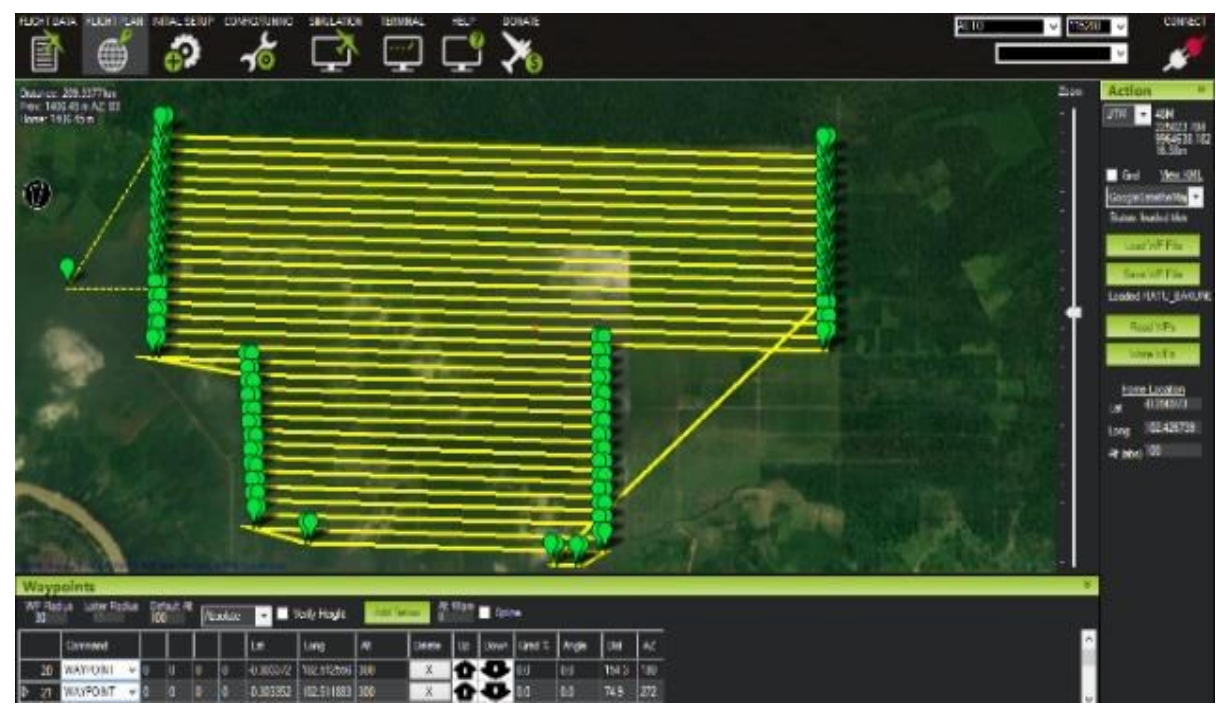

Gambar 6. Persiapan Pemotretan dan Pembuatan Jalur Terbang. 


\section{Pemotretan Drone}

Langkah pemotretan dilakukan dengan memulai membuat jalur terbang menggunakan software mission planner. Tinggi pesawat pada kisaran 300-350 mdpal, dengan jarak foto setiap $40 \mathrm{~m}$. Resolusi citra drone yang dihasilkan per piksel pada kisaran 9-10 cm. Ada 7 Penerbangan yang dirancang dengan masing-masing penerbangan menempuh jarak 50-60 $\mathrm{Km}$ dengan kecepatan pesawat 10-12 m/detik. Dengan jarak tempuh tersebut dibutuhkan waktu 4560 menit untuk setiap penebangan. Secara jelas dapat dilihat pada gambar 6 .

\section{Mozaik Citra}

Ada 7 penerbangan yang masing- masing penerbangan memuat kurang lebih 1000 foto. Foto-foto ini sudah geotaging atau mempunyai referensi koordinat. Mozaik adalah proses menggabungkan beberapa foto sehingga menjadi satu kesatuan. Penggabungan berdasarkan kesamaan koordinat dan kemiripan objek.

Software yang digunakan untuk penggabungan data adalah agisoft photoscan. Dengan menggunakan komputer processor Intel core 17 dan memori $32 \mathrm{~GB}$, untuk membuat mozaik 1000 foto dengan ukuran masing-masing foto kurang lebih 3 Mb dibuatuhkan waktu sekitar 1 jam. Gambar mozaik citra drone dapat dilihat pada gambar 7.

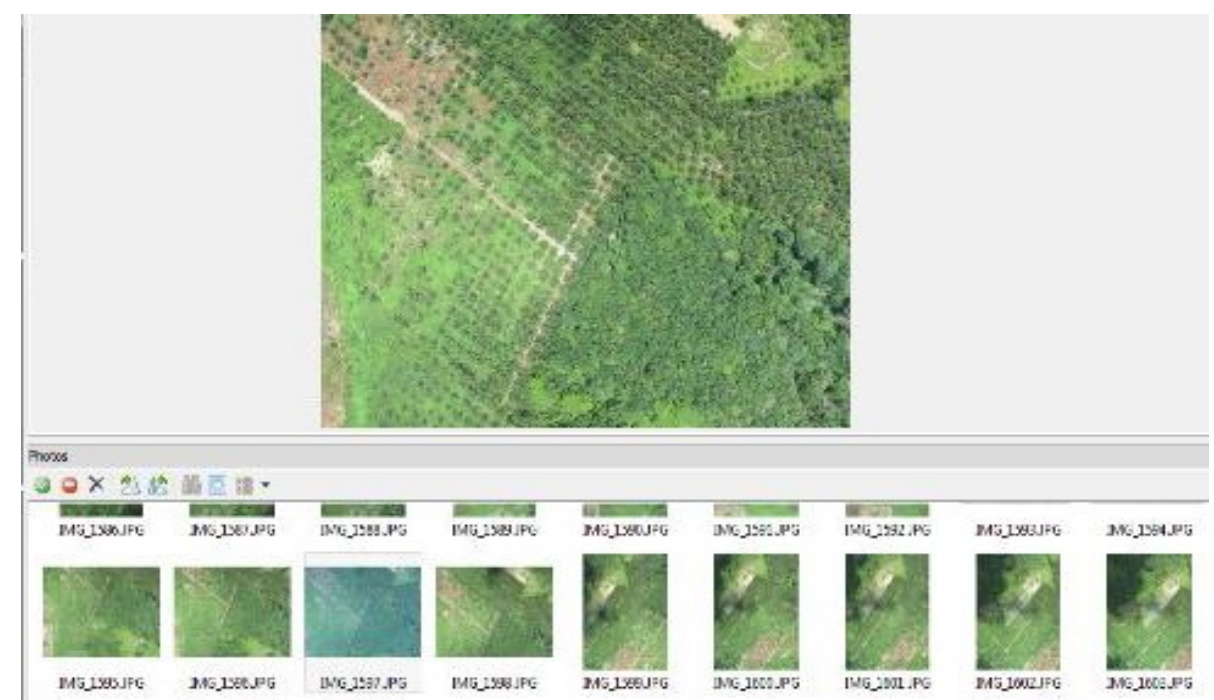

Gambar 7. Mozaik Foto Daerah Penelitian

\section{Rektifikasi Foto Drone}

Rektifikasi merupakan koreksi lokasi koordinat yang ada pada foto dengan posisi sebenarnya di lapangan. Ada 8 titik yang dibuat dengan dasar penggambilan titik yaitu pada lokasi yang mudah diketahui dari foto dan lapangan. Lokasi ini berupa perempatan jalan, perpotongan jalan dengan sungai, patok-patok BPN dengan ukuran $40 \mathrm{~cm}$ x 40 $\mathrm{cm}$. Lokasi titik diambil koordinatnya menggunakan GPS Trimble GeoXT 4000 dan Trimble Geodetic R4 untuk post processing.

Dengan ketelitian sub meter diharapkan foto udara yang diambil lebih akurat dan presisi sehingga meminimalkan kesalahan ketika pengerjaan.

Komposit warna asli 321 (visible) dan inframerah 432

Pada komposit warna asli menggunakan panjang gelombang biru, hijau dan merah. Dengan panjang gelombang 0,4 - 0,7 $\mu \mathrm{m}$. Pada komposit ini warna sawit sesuai dengan warna asli di lapangan. Sawit yang tidak sehat sudah dapat dibedakan secara manual, yaitu dengan membedakan warna, ukuran, dan luas tajuk selengkapnya Gambar 8. 
ISSN: $1411-8548$

E-ISSN: 2580-5274

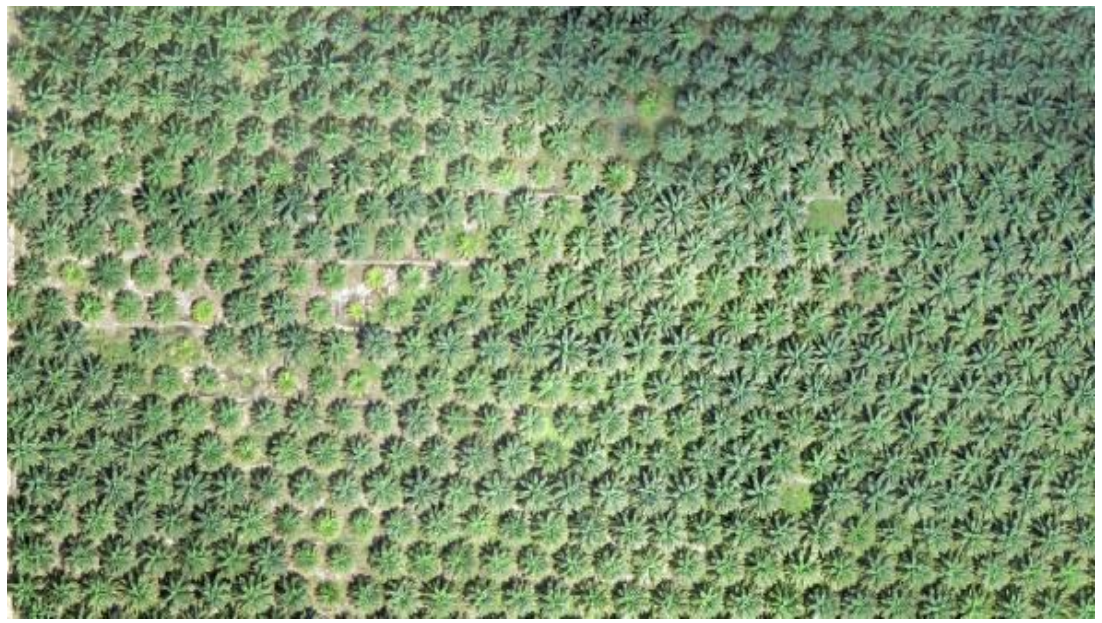

Gambar 8. Foto Drone Daerah Penelitian Menggunakan Sensor Visible

Pada citra drone diatas pohon sawit dengan warna hijau kekuningan terindikasi kurang sehat dan pertumbuhanya terganggu. Citra drone komposit inframerah menggunakan komposit 432 yaitu inframerah dekat, gelombang merah dan hijau. Pada komposit ini objek vegetasi berupa daun sawit paling tinggi dipantulkan oleh inframerah dan diserap oleh saluran merah, untuk lebih jelasnya pada gambar 3.2 tentang kurfa pantulan.

Dengan komposit 432 maka dihasilkan foto drone yang didominasi warna merah sebagai efek dari pantulan daun kelapa sawit. Berikut adalah gambar foto drone komposit 432 daerah penelitian.

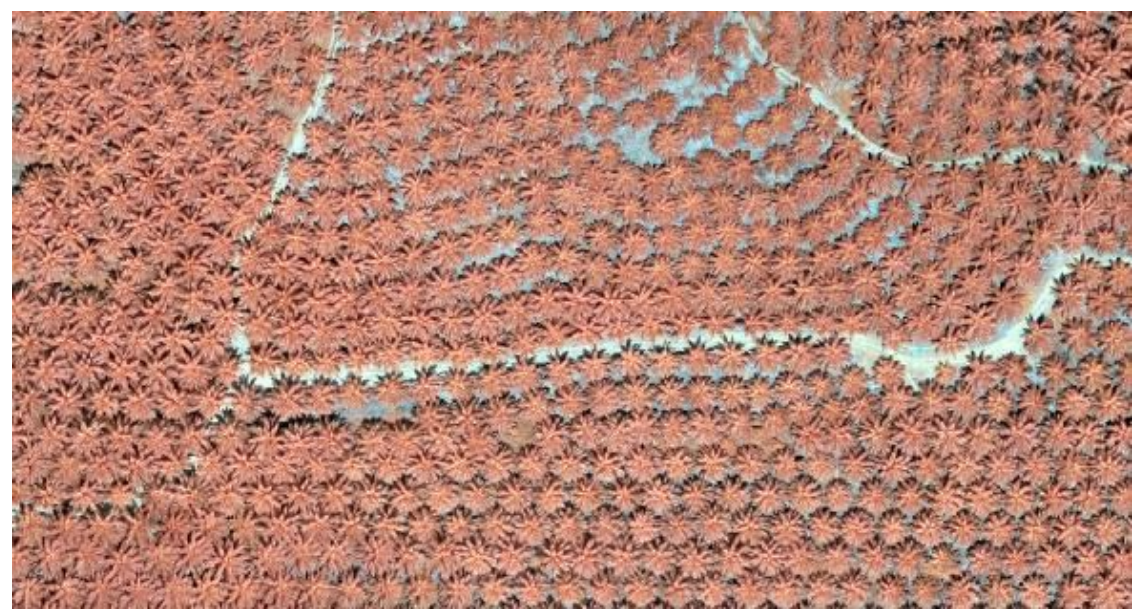

Gambar 9. Komposit 432 Menggunakan Panjang Gelombang Inframerah Dekat.

\section{Analisis Drone untuk Memonitor Kesehatan Kelapa Sawit.}

Berdasarkan komposit warna asli dan warna semu maka ada 2 pendekatan yang digunakan yaitu analisis visual dan digital.

\section{a. Analisis Visual}

Pada analisis ini digunakan citra komposit warna asli, dengan melakukan interpretasi sawit dan bukan sawit. Setiap pokok sawit ditandai menggunakan titik pada citra. Penggunaan titik ini juga memungkinkan digunakan untuk menghitung jumlah pokok sawit. Dari titik- titik yang ditandai kemudian dibuat radius jarak sesuai dengan luasan tajuk.

Sehingga membentuk lingkaranlingkaran kecil luasan tajuk. Setiap pohon dapat dianalisis berdasarkan informasi luasan tajuk berdasarkan umur tanaman yang didapat dari data sekunder seperti pada Gambar 10. 


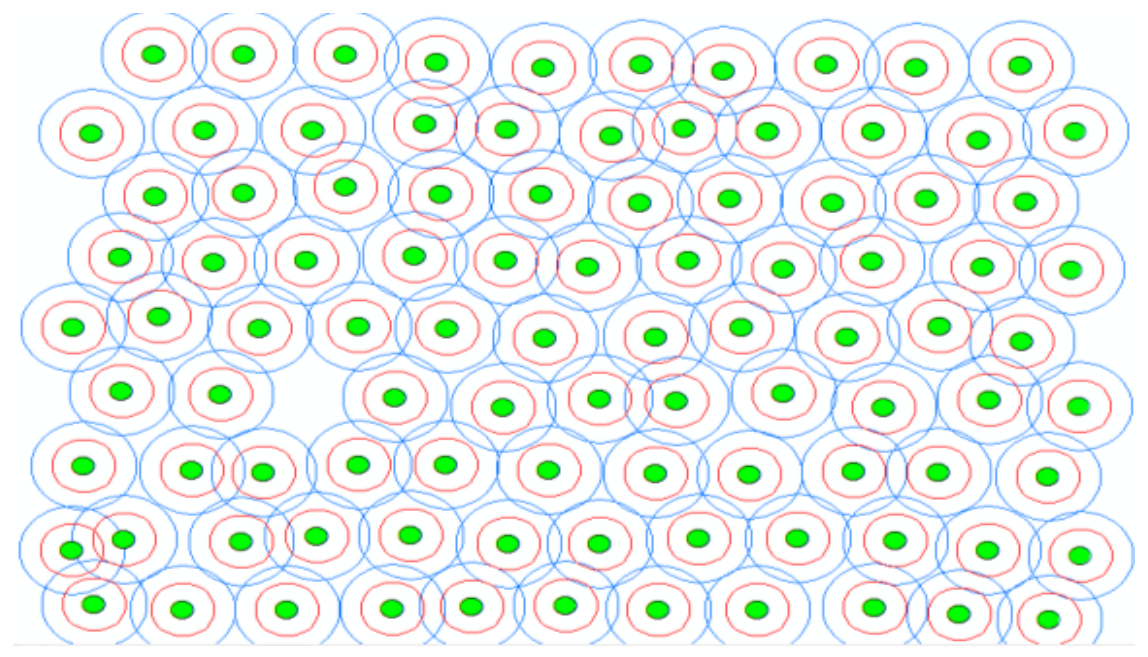

Gambar 10. Analisis Visual

Pada gambar 10 kemudian dilakukan buffer terhadap tanaman yaitu jarak 0-3 m dan 4-5 m. setiap ukuran tajuk mewakili karakteristik sendiri pada sawit. Ukuran 0-3 $\mathrm{m}$ berarti pertumbuhan masih terhambat dan ukuran 3-5 m berarti normal. Sehingga hasil buffer akan menjadi seperti pada gambar 11.

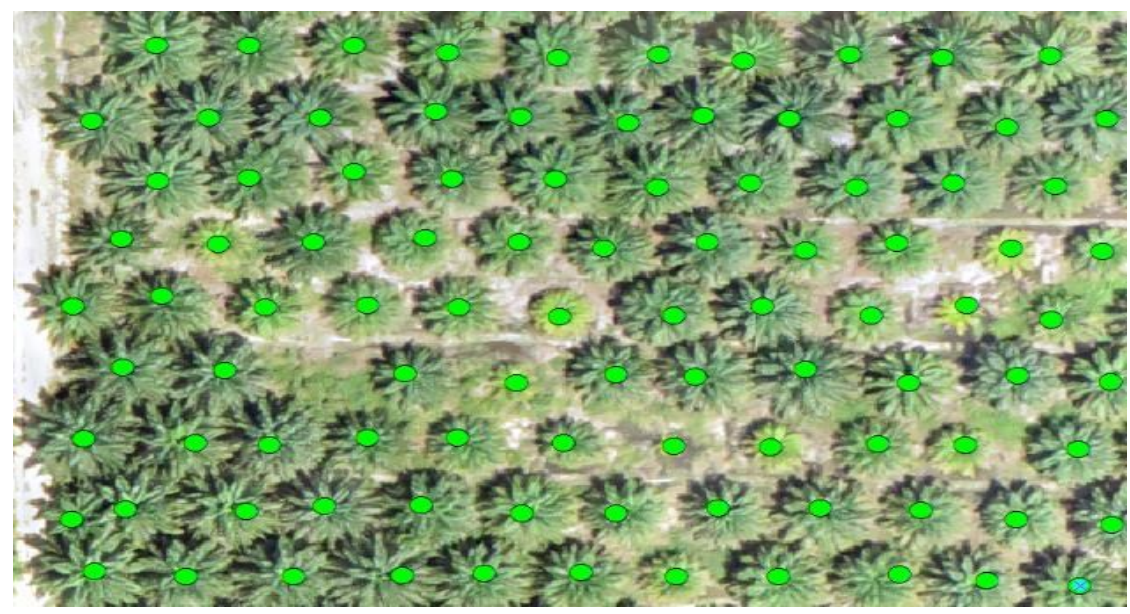

Gambar 11. Buffer Ukuran Tajuk Sawit (Merah 0-3 m, biru 3-5 m)

\section{b. Analisis Digital NDVI}

NDVI (Normalized Diferrent Vegetation Index) merupakan indeks vegetasi yang dapat digunakan untuk melihat tingkat kehijauan tanaman sawit yang berhubungan dengan fotosintesis tanaman sawit. Dengan asumsi bahwa semakin aktif proses fotosintesis (tanaman sehat) nilai NDVI akan semakin tinggi dan sebaliknya semakin kurang sehatnya atau semakin rendah tingkat kehijauan tanaman (hijau daun tidak menutupi seluruh permukaan tanah dan tidak/kurang subur) akan memberikan nilai NDVI yang semakin rendah. 


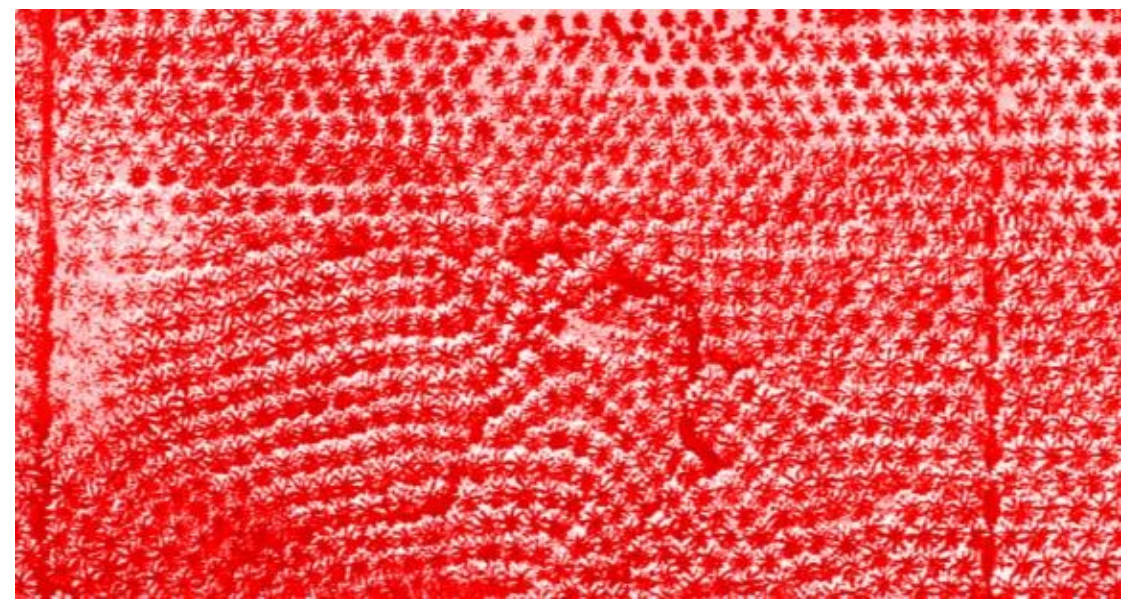

Gambar 12. NDVI dengan Pengkelasan

Pada kelas 1 menunjukan nilai kemerahan yang tinggi menandakan kesehatan kelapa sawit. Semakin cerah menandakan semakin rendah kandungan zat hijau daun.
Peta Kesehatan Kelapa Sawit

Overlay antara pekerjaan secara visual dengan pekerjaan secara digital akan menghasilkan identifikasi kesehatan tanaman kelapa sawit yang lebih tinggi. Berikut adalah hasil analisis overlay dari kedua metede tersebut.

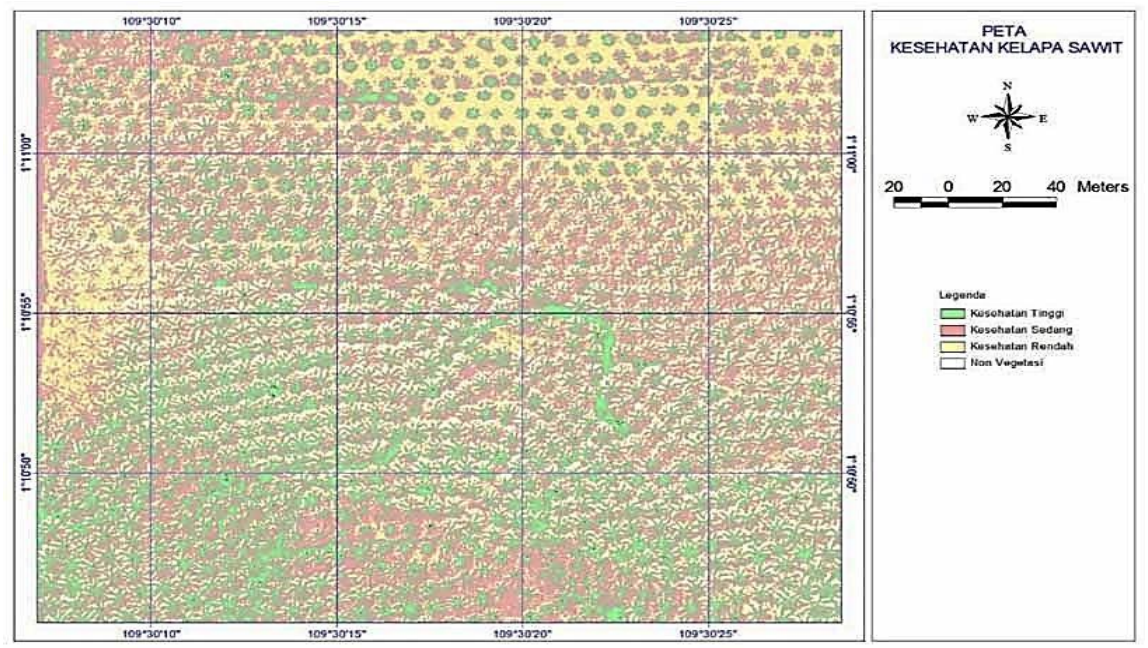

Gambar 13 Peta Kesehatan Tanaman Kelapa Sawit dari Citra Drone 2019

\section{KESIMPULAN}

1. Citra drone sangat membantu dalam identifikasi kesehatan tanaman sawit mengingat luasnya lahan sawit.

2. Penggabungan metode visual dengan komposit 321 warna asli (visible) dengan metode digital menggunakan inframerah sangat baik digunakan dan nantinya akan saling mengkoreksi sehingga tingkat keakuratan data menjadi bertambah.

\section{DAFTAR PUSTAKA}

Driscoll, J. O. (2018). Journal of Archaeological Science: Reports Landscape applications of photogrammetry using unmanned aerial vehicles. Journal of Archaeological Science: Reports, 22(September), 32-44. https://doi.org/10.1016/j.jasrep.2018.09 .010 
Duffy, J. P., Pratt, L., Anderson, K., Land, P. E., \& Shutler, J. D. (2018). Estuarine , Coastal and Shelf Science Spatial assessment of intertidal seagrass meadows using optical imaging systems and a lightweight drone. Estuarine, Coastal and Shelf Science, 200, 169-180. https://doi.org/10.1016/j.ecss.2017.11. 001

Dugdale, S. J., Malcolm, I. A., \& Hannah, D. M. (2019). Science of the Total Environment Drone-based Structurefrom-Motion provides accurate forest canopy data to assess shading effects in river temperature models. Science of the Total Environment, 678, 326-340. https://doi.org/10.1016/j.scitotenv.2019. 04.229

Mirzaeinia, A., Hassanalian, M., Lee, K., \& Mirzaeinia, M. (2019). Energy conservation of $\mathrm{V}$-shaped swarming fixed-wing drones through position reconfiguration. Aerospace Science and Technology, 94, 105398. https://doi.org/10.1016/j.ast.2019.1053 98

Poljak, M., \& Sterbenc, A. (2019). Use of drones in clinical microbiology and infectious diseases: current status, challenges and barriers, (xxxx). https://doi.org/10.1016/j.cmi.2019.09.0 14

Saria, M. H. D., \& Al-sa, M. F. (2019). Data in brief DroneRF dataset: A dataset of drones for RF- based detection , classi fi cation and identi fi cation, 26. https://doi.org/10.1016/j.dib.2019.1043 13
Sciancalepore, S., Ibrahim, O. A., Oligeri, G., Pietro, R. Di, Sciancalepore, S., Ibrahim, O. A., \& Oligeri, G. (2019). $\mathrm{PiNcH}$ : an Effective, Efficient, and Robust Solution to Drone Detection via Network Traffic Analysis. Computer Networks, 107044. https://doi.org/10.1016/j.comnet.2019.1 07044

Siva, K. C. (2016). Robotic-Based Agriculture for Rural Renaissance: Drones and Biosensors. Comprehensive Analytical Chemistry (Vol. 74). Elsevier Ltd. https://doi.org/10.1016/bs.coac.2016.0 4.017

Tu, Y., Phinn, S., Johansen, K., Robson, A., \& Wu, D. (2020). ISPRS Journal of Photogrammetry and Remote Sensing Optimising drone flight planning for measuring horticultural tree crop structure. ISPRS Journal of Photogrammetry and Remote Sensing, 160(November 2019), 83-96. https://doi.org/10.1016/j.isprsjprs.2019. 12.006

Watkins, S., Burry, J., Mohamed, A., Marino, M., Prudden, S., Fisher, A., ... Clothier, R. (2019). Ten Questions Concerning the Use of Drones in Urban Environments. Building and Environment, 106458. https://doi.org/10.1016/j.buildenv.2019. 106458 